\title{
Effect of TEAT PROTECT spray and potassium permanganate teat dip in curing subclinical mastitis in crossbred cows of Villupuram district of Tamilnadu
}

\section{Sukumar*}

Department of Livestock Production Management, Madras Veterinary College, Chennai600007 (Tamilnadu), India

Thanga. Thamil Vanan

Department of Livestock Production Management, Madras Veterinary College, Chennai600007 (Tamilnadu), India

\section{A.Thennarasu}

Veterinary University Training and Research Centre, Dharmapuri-636703 (Tamilnadu), India

\section{T.M.A. Senthil Kumar}

Central University Laboratory, Chennai-600051 (Tamilnadu), India

*Corresponding author. E-mail: drdsukumar1968@gmail.com

\begin{abstract}
A study was undertaken to assess the incidence of subclinical mastitis in crossbred cows of Villupuram district by using direct microscopic Somatic cell count (SCC). For this purpose sixty eight crossbred cows positive for subclinical mastitis (SCM) as per IDF (International Dairy Federation) criteria were randomly allotted in to two treatment groups. The cows in T1 group were subjected to post milking teat dip with one per cent Potassium permanganate $\left(\mathrm{KMnO}_{4}\right)$ solution immediately after milking. The cows in T2 group were sprayed with TEAT PROTECT sprays. Sixteen healthy cows were kept as control group and udder was washed with plain water. The treatments were carried out for 30 days. Udder health status was determined by recording the parameters viz. somatic cell count (SCC), average daily milk yield, udder colony count and teat colony count. The results revealed that TEAT PROTECT spray is superior to Potassium permanganate in curing SCM of crossbred cows.
\end{abstract}

Keywords: $\mathrm{KMnO}_{4}$ teat dip, Somatic cell count, Subclinical mastitis, TEAT PROTECT spray

\section{INTRODUCTION}

Mastitis is a major and perpetual problem of the dairy sector due to failure to follow basic management practices under field conditions incurring heavy financial losses as a result of reduction in milk yield, cost of treatment, loss due to discarded milk and loss of germ plasm due to culling of superior animals. The economic losses due to subclinical mastitis were estimated in the range of INR 21,677 to INR 88,340 per lactation (Rathod et al., 2017). Subclinical mastitis in cattle and buffaloes is estimated to result in a loss of Rs.1592.87 and Rs. 892.42 per lactation, respectively (Sinha et al., 2014).

The subclinical form of the disease is 15 to 40 times more prevalent than its clinical counterpart, difficult to diagnose and usually persist longer in the herd causing production losses. Biswaadeep et al. (2015) carried out a cross sectional study to determine the prevalence of bovine subclinical

\section{Article Info}

https://doi.org/

10.31018jans.v11i3.2148

Received: July 17, 2019

Revised: September 5, 2019

Accepted: September 9, 2019

\section{How to Cite}

Sukumar, D. et al. (2019) Effect of TEAT PROTECT spray and potassium permanganate teat dip in curing subclinical mastitis in crossbred cows of Villupuram district of Tamilnadu. Journal of Applied and Natural Science, 11 (3): $738-742$ https:// doi.org/10.31018jans.v11i3 .2148 mastitis in Jaipur district of Rajasthan. They recorded a high prevalence of subclinical mastitis in animal level, $67.27 \%$ and $74.55 \%$ by CMT and SCC respectively. They attributed this high prevalence to improper sanitation of environment, udder and milker's hand.

Rathod et al. (2017) investigated the incidence rate of subclinical mastitis in Bidar, Karnataka. They have observed that poor hygiene of milkman in terms of health condition, zoonotic diseases, clean clothing, and proper hand washing before and after milking with antiseptic solution, also caused SCM in the dairy animals. The crossbred cows which contribute 85.2 per cent of the total milk production of Tamil Nadu are more vulnerable for mastitis because of stress due to higher productivity, inadequate feeding and tropical climate. Hence a study was conducted to compare the efficacy of a novel product (TEAT PROTECT spray) and one per cent Potassium permanganate $\left(\mathrm{KMnO}_{4}\right)$ teat dip in curing SCM in crossbred cows 


\section{MATERIALS AND METHODS}

One hundred apparently healthy cows of Villupuram district were selected by multistage random sampling technique. The milk samples were screened by SCC method and interpretations was done as per Sing (2015). A cow with at least one quarter affected at the time of examination was considered positive for subclinical mastitis. The sixty eight crossbred cows positive for subclinical mastitis (SCM) as per IDF criteria and were randomly allotted in to two treatment groups. The cows in T1 group were subjected to post milking teat dip with one per cent Potassium permanganate $\left(\mathrm{KMnO}_{4}\right)$ solution immediately after milking. The cows in T2 group were sprayed with TEAT PROTECT sprays. Sixteen healthy cows were kept as control group and udder was washed with plain water. The treatments were carried out for 30 days.

Potassium permanganate Post teat dipping protocol: The cows in T1 group were provided post milking teat dip with one per cent Potassium Permanganate solution immediately before and after milking. The udder and teat of the animals were first washed with clean water and dried with clean cloth. Immediately after milking, nearly the whole external surface of the teat was dipped into dipping solution (one per cent Potassium Permanganate) which was left for about 30 seconds and teat was then dried by another clean cloth. The farmers were trained and requested to adopt the dipping practice for 30 days. After 30 days, milk samples were collected from animals and subjected to direct microscopic Somatic Cell Count and the values were recorded and compared with values of day 0 .

Teat Protect spray protocol: In T2 group of cows the udder and teat of the animals were washed with clean water and dried with clean cloth, and the Teat-protect spray was applied onto the udder after milking. The gel was washed off just prior to subsequent milking. The farmers were trained and requested to adopt the practice for 30 days. After 30 days, milk samples were collected from animals and subjected to direct microscopic Somatic Cell Count and the values recorded and compared with values of day 0 .

Control protocol: The udders of control animals were washed with plain water and dried with clean cloth for 30 days and milk samples were collected from animals and subjected to direct microscopic Somatic Cell Count and the values recorded and compared with values of day 0 .

Milk collection procedure: Milk sample collection was carried out as per Biswaadeep et al., (2015). At first quarters were washed thoroughly with lukewarm water and dried. The teat end of the quarter was swabbed with cotton soaked with $70 \%$ alcohol. The first 3-4 streams of milk were discarded and milk samples were taken from each quarter prior to the milking in separate clean containers. The containers were marked as right fore $(R F)$, right hind $(R H)$, left fore (LF) and left hind (LH) and collection was done first from near side and then from off side to avoid contamination of teat apices

Collection of teat and udder swab: The collection of udder and teat swabs was done as per Hubaety et al., (2013). Sterile cotton swabs manufactured by HIMEDIA and supplied by TRPVB were used for sampling. Swabs were streaked on five locations of an area of $16 \mathrm{~cm} 2$ and placed in test tubes containing peptone saline, and transferred to the TRPVB laboratory (Centre for Animal Health Studies), TANUVAS in a cool box immediately for enumeration of CFU/swab. Colony counting of udder and teat swabs was performed on day 0 and day 30 of the trial as per USDA APHIS standard plate count protocol.

Collection of data of milk yield: The daily average milk yield in liters on day 0 and day 30 in the two treatment groups and control group were recorded

Direct microscopic counting of SCC: The estimation of somatic cell count (SCC) was carried out as per Singh(2015) involving the following steps.

Preparation of milk smears: Milk sample was thoroughly mixed, so as to obtain uniform distribution of cells. Ten micro liter of milk $(0.01 \mathrm{ml})$ from each quarter was spread over $1 \mathrm{~cm}^{2}$ marked area on a grease free glass slide with the help of a platinum loop. The smears on the slides were left undisturbed at room temperature, air dried and preserved till staining was done.

Staining: The smear was fixed in Xylol for 5 minutes and stained with modified Lempert Newman stain by immersing in the stain for 20 seconds. Excess of stain was drained off and slides were air-dried. Then the slides were rinsed two or three times in water, drained, and rapidly air-dried, by gentle blotting with a filter paper. The smears were stained deep blue.

Calculation of working factor (WF) of the microscope: A binocular microscope was used with 10x oculars and $1.8 \mathrm{~mm}$ oil immersion objective. The diameter of the field was measured with the help of a stage micrometer.

Diameter of microscopic field $=0.16 \mathrm{~mm}$ or 0.016 $\mathrm{cm}$

Area of the field $=\pi r 2=3.14 \times(0.008) 2=0.0002$ sq.cm

Since $0.01 \mathrm{ml}$ of milk was spared in $1.0 \mathrm{~cm} 2$, the possible number of fields counted in $1 \mathrm{sq} . \mathrm{cm}$ is 5000 .

Milk volume represented by each field $=1 / 5000 \mathrm{x}$ $1 / 100=1 / 500000 \mathrm{ml}$.

Hence, microscopic factor $(M F)=5,00,000$ 
Working factor $(\mathrm{WF})=\mathrm{MF} /$ No. of fields counted i.e. $500000 / 25=20000$

No. of cells per $\mathrm{ml}=$ Total no. of cells counted in 25 fields $\times$ WF (20000)

Cell counting: Cell counting was made by examining the smears under oil immersion objective as per the procedure used by Singh(2015). The cells were counted in 25 fields. Total number of cells counted was multiplied with the working factor to obtain the number of cells per ml of milk

Interpretation of counting results: Sample showing somatic cell count more than 5, 00, 000 cells is considered as positive case for subclinical mastitis as per the criteria cited by International Dairy Federation (IDF) and Hegde et al., (2013).

Statistical analysis: The SCC values, teat swab and udder swab colony counts and daily average milk yield before and after treatment as observed in treatment and control groups analyzed by applying paired ' $t$ ' test using IBM $®$ SPSS $® 23$ of windows.

After solidification of agar, the plates were incubated in inverted position at $37^{\circ} \mathrm{C}$ for 24 hours. After incubation, bacterial cells grow into distinct colonies, which were counted with colony counter.

\section{RESULTS AND DISCUSSION}

The results of paired ' $\mathrm{t}$ ' test are presented in Table -1 . In the $\mathrm{KMnO}_{4}$ group, the mean $\pm \mathrm{SD}$ of SCC values $\left(\times 10^{5}\right.$ cells $\left./ \mathrm{ml}\right)$ of the right fore, right hind, left fore and left hind quarters of crossbred cows showed a significant $(P<0.01)$ reduction from $3.67 \pm 0.232$ to $1.14 \pm 0.239, \quad 5.80 \pm 0.361$ to $3.57 \pm 0.225, \quad 4.09 \pm 0.248$ to $3.33 \pm 0.191$ and $9.77 \pm 0.404$ to $6.44 \pm 0.293$ respectively during the trial period. The mean $\pm S D$ of the udder and teat colony count $(\log 10 \mathrm{cfu} / \mathrm{ml})$ also showed a significant reduction $(P<0.01)$ from $4.987 \pm 0.080$ to $2.825 \pm 0.060$ and from $4.97 \pm 0.073$ to $2.776 \pm 0.058$ during the trial period. The mean $\pm S D$ of the average daily milk yield (liters) also showed an increase from $10.38 \pm 1.859$ to $10.41 \pm 1.909$. This was in agreement with the observations of Hubaety et al. (2013) and Yasothai (2017) who envisaged positive results upon the usage of pre and post milking dip in cross bred dairy cattle. In contrary to these reports. Abinaya and Thangarasu (2017) have observed that suggested that one per cent of potassium permanganate solution is clinically not effective to control mastitis in dairy cows (Table-1).

In the TEAT PROTECT group, the mean \pm SD of SCC values $\left(\times 10^{5}\right.$ cells $\left./ \mathrm{ml}\right)$ of the right fore, right hind, left fore and left hind quarters showed a significant $(P<0.01)$ reduction from $3.22 \pm 0.291$ to $2.52 \pm 0.149, \quad 6.01 \pm 0.351$ to $3.61 \pm 0.199$, $4.11 \pm 0.241$ to $2.92 \pm 0.177$ and $9.01 \pm 0.348$ to $4.54 \pm 0.274$ respectively during the trial period. The mean $\pm S D$ of the udder and teat colony count (log $10 \mathrm{cfu} / \mathrm{ml})$ also showed a significant reduction 


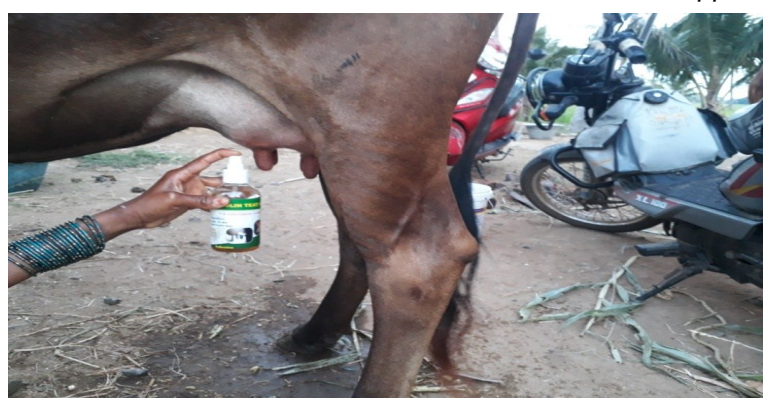

Fig. 1. Application of TEAT PROTECT spray on the teats of cow.

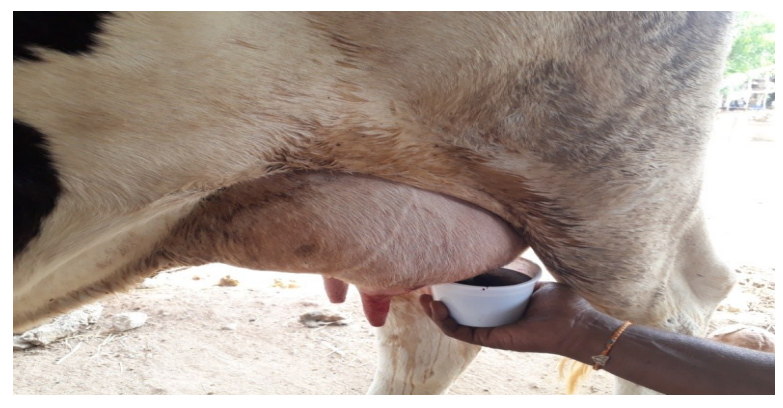

Fig. 2. Application of $\mathrm{KMnO}_{4}$ teat dip to the teats of cow.

Table 2. Quarter cure rate (per cent) in different treatment and control groups of crossbred cows by screening with SCC in Villupuram district of Tamil Nadu and its analysis.

\begin{tabular}{|c|c|c|c|c|c|c|c|c|c|c|c|c|}
\hline \multirow{3}{*}{ Result } & \multicolumn{4}{|c|}{ T-1: $\mathrm{KmnO}_{4}$ teat dip } & \multicolumn{4}{|c|}{ T-2: TEAT PROTECT spray } & \multicolumn{4}{|c|}{ Control (Water wash) } \\
\hline & \multicolumn{2}{|c|}{$\begin{array}{l}\text { Days of } \\
\text { trial }\end{array}$} & \multirow{2}{*}{$\begin{array}{l}\text { Quarter } \\
\text { Cure per } \\
\text { cent }\end{array}$} & \multirow{2}{*}{$\begin{array}{l}\text { Chi- } \\
\text { square } \\
\text { value }\end{array}$} & \multicolumn{2}{|c|}{$\begin{array}{l}\text { Days } \\
\text { trial }\end{array}$} & \multirow{2}{*}{$\begin{array}{l}\text { Quarter } \\
\text { Cure per } \\
\text { cent }\end{array}$} & \multirow{2}{*}{$\begin{array}{l}\text { Chi- } \\
\text { square } \\
\text { value }\end{array}$} & \multicolumn{2}{|c|}{$\begin{array}{l}\text { Days of } \\
\text { trial }\end{array}$} & \multirow{2}{*}{$\begin{array}{l}\text { Quarter } \\
\text { Cure per } \\
\text { cent }\end{array}$} & \multirow{2}{*}{$\begin{array}{l}\text { Chi- } \\
\text { square } \\
\text { value }\end{array}$} \\
\hline & 0 & 30 & & & 0 & 30 & & & 0 & 30 & & \\
\hline Positive & 57 & 30 & 27 & 12 & 60 & 12 & 48 & $1352^{* *}$ & 0 & 16 & & \\
\hline Negative & 79 & 106 & (47.36) & 12.52 & 76 & 124 & $(80.00)$ & 43.52 & 68 & 48 & $(0.00)$ & 18.29 \\
\hline
\end{tabular}

$(P<0.01)$ from $4.97 \pm 0.070$ to $2.87 \pm 0.461$ and from $4.968 \pm 0.098$ to $2.775 \pm 0.571$ during the trial period. The mean $\pm S D$ of the average daily milk yield (liters) also showed a significant $(P<0.01)$ increase from $10.76 \pm 1.986$ to $11.35 \pm 0.2 .013$. This was in agreement with the observations of Adarsh et al., (2015) and Krishnakumar et al. (2017) studied the effect of herbal spray (AV/AMS/15), by treating 10 cows positive for SCM and observed that the average SCC values got reduction of 24.6 per cent of the cell count.

In the control group, the mean \pm SD of SCC values $\left(\times 10^{5}\right.$ cells $\left./ \mathrm{ml}\right)$ of the right fore, right hind, left fore and left hind quarters showed an increase from $2.67 \pm 0.138$ to $3.94 \pm 0.352,2.66 \pm 0.152$ to $4.37 \pm 0.474$, a significant increase $(P<0.05)$ from $2.45 \pm 0.153$ to $4.16 \pm 0.413$ and significant increase $(P<0.05)$ from $3.02 \pm 0.160$ to $5.92 \pm 0.542$ respectively during the trial period. The mean $\pm S D$ of the udder and teat colony count $(\log 10 \mathrm{cfu} / \mathrm{ml})$ also showed a significant $(P<0.01)$ increase from $4.76 \pm 0.153$ to $4.97 \pm 0.302$ and $4.86 \pm 0.086$ to $4.98 \pm 0.049$ during the trial period. The mean $\pm S D$ of the average daily milk yield (liters) showed a significant $(P<0.05)$ reduction from $10.75 \pm 1.807$ to $9.25 \pm 1.693$.

The results showed that the application of teat protect spray for 30 days was highly effective in curing SCM as there was a significant $(P<0.01)$ reduction in $\mathrm{mCMT}$ score and TANUCHEK score as well as, the SCC values in all the four quarters were significantly $(P<0.01)$ brought below the cutoff levels fixed by IDF. But, application of 1 per cent $\mathrm{KMnO}_{4}$ post milking teat dip for 30 days cured three quarters, as left hind quarters had SCC values above the IDF cut-off levels. The use of 1 per cent $\mathrm{KMnO}_{4}$ post milking teat dip for another 30 days might cure all four quarters and further research is required in this context. In the control group, there was significant reduction of daily average milk yield, increase in the SCC values of all four quarters and significant increase in udder and teat colony count.

The results of quarter cure rates are presented in Table-2. In cows treated with $\mathrm{KmnO}_{4},(\mathrm{~T}-1)$ a significant quarter cure per cent $(P<0.01)$ was observed (47.36 per cent) as screened by SCC methods. (Table- 2) A significant $(P<0.01)$ cure rate of 80.00 per cent was observed in cows treated with TEAT protect spray (T-2) as screened by SCC method and the TEAT protect spray was found superior to $\mathrm{KMnO}_{4}$ in curing quarters of crossbred cows affected by SCM. There was a significant $(P<0.01)$ incidence of new SCM infections that were observed in control group of cows which were negative for SCM at the beginning of the trial.

\section{Conclusion}

The TEAT protect spray was found superior to $\mathrm{KMnO}_{4}$ in curing quarters of crossbred cows affected by SCM. There was a significant $(P<0.01)$ incidence of new SCM infections that were observed in control group of cows. Regular application of a trusted germicidal spray like TEAT PROTECT is highly recommended to keep the levels of SCC below the cut-off point prescribed by the IDF and to increase milk production.

\section{ACKNOWLEDGEMENTS}

Authors are thankful to the Dean, Madras Veterinary College for providing necessary facilities for carrying out the present work and the Project Director, TRPVB, TANUVAS, Chennai for provision of inputs and technical support to the research. 


\section{REFERENCES}

1. Abinaya, $P$ and Thangarasu, S. (2017). Testing the efficacy of Potassium permanganate as antiseptic for the control of bovine mastitis. Int.J. Curr. Microbiol. App. Sci. 6 (10): 609-611.

2. Adarsh, N. S. Ranaut, S. Gupta, S. Ma ini, K. Ravikanth, (2015). Efficacy evaluation av/ amp/34, mastilep gel, herbal spray (av/ams/15) in sub clinical mastitis in bovines. ijprbs, 4(3): 154-159.

3. Biswadeep, J., N. K. Pagrut, A. Sahoo and A. Ahmed, (2015). Subclinical bovine mastitis in Rural Peri-urban and Suburban regions of Jaipur District of Rajasthan, India. Journal of Animal Research., 5(1): 175-182

4. Hegde, R., Shrikrishna. K. Nithin Prabhu, B. R. Shome, D. Rathnamma, V. V. S. Suryanarayana, S. Yatiraj, C. Renuka Prasad, N. Krishnaveni, S. Sundareshan, D. S. Akhila, A. R. Gomes, Nagendra R. Hegde, (2013). Incidence of Subclinical Mastitis and Prevalence of Major Mastitis Pathogens in Organized Farms and Unorganized Sectors. Indian J Microbiol, 53(3): 315-320.

5. Hubaety, A. K. AL., R. H. Awad, R.I. THanon and F.A.Ez-Aldin, (2013). Udder preparation and its effect on udder cleanliness and milk quality. AL-Qadisiya
Journal of Vet.Med.Sci.12: 128-138.

6. Krishnakumar, S., V. Yadav, Anurag borthakur and K. Ravikanth. (2017). Efficacy evaluation of topical herbal spray in subclinical mastitis in bovines. World journal of pharmaceutical and medical research, 3 (8): 172-175

7. Rathod, P. K., V. Shivamurthy and Anant Rao Desai, 2017. Economic Losses due to Subclinical Mastitis in Dairy Animals: A Study in Bidar District of Karnataka. Indian. J. Vet. Sci. Biotech., 13(1): 3741.

8. Singh, M., (2015). Microbiological and immunological studies on buffalo subclinical mastitis. Ph.D. Thesis, L. L. R. University of Veterinary and Animal Sciences, Hisar.

9. Sinha, M. K., N. N. Thombare and B. Mondal, (2014). Subclinical Mastitis in Dairy Animals: Incidence, Economics, and Predisposing Factors. Hindawi Publishing Corporation, Scientific World Journal., 2014 523984, 4 pages

10.Yasothai, R., (2017). Comparison of Diagnostic Tests for the Detection of Sub-Clinical Mastitis in Dairy Farms of Erode District. International Journal of Science, Environment and Technology,, Vol. 6, No 2, $1321-1326$. 